\title{
The role of ambient temperature variation on drying shrinkage development of self-compacting Portland-limestone cement concrete
}

\author{
Basil Al-Shathr ${ }^{1}$, Ammar Abdulameer ${ }^{1, *}$ and Tareq al-Attar ${ }^{1}$ \\ ${ }^{1}$ Building and Construction Engineering Department, University of Technology, Baghdad, Iraq
}

\begin{abstract}
The ambient temperature records in Iraq show a large variation between day and night reaching $20 \mathrm{C}$, depending on the season, whether it is summer or winter. For this reason, the aim of this research is to study the effect of these conditions on the drying shrinkage of self-compacting concrete produced by using Portland-Limestone cement (ASTM C595 - Type IL). SCC mixes were designed to attain compressive strengths of 40 and $60 \mathrm{MPa}$ at 28 days with and without silica fume respectively. Same mixes were reproduced with ordinary Portland cement (ASTM C150 - Type I) for comparisons. Two maximum sizes of aggregate 10 and $20 \mathrm{~mm}$ were incorporated in this work. The drying shrinkage was measured for 180 days after 7 days of water curing. The range of ambient (outdoor) temperature variation was from -4 to $+39{ }^{\circ} \mathrm{C}$ and the relative humidity ranged from 15 to $60 \%$. The results of this exposure were compared to that of specimens kept in the shrinkage chamber, with a temperature of $21{ }^{\circ} \mathrm{C}$ and relative humidity $35 \%$. The current results showed that due to the irreversible nature of shrinkage strain, the drop of ambient temperature and the rise of atmosphere moisture or relative humidity would not reverse the shrinkage strain. It is important to figure the final total accumulated strain when dealing with ambient temperature variation. The drying shrinkage characteristics for concrete made with Type IL cement, are found similar to that for concrete produced with Type I cement.
\end{abstract}

\section{Introduction}

Drying shrinkage is a major cause of the concrete deterioration especially in Middle East region, thus the acknowledgement of the shrinkage deformation needs to be evaluated. Ingram and Daugherty [1] indicated that in many countries some limestone are allowed to be added to Portland cement products, and by controlling the properties of the cement they will be able to produce products that are both ethically and economically viable. Sivilis et al. [2] concluded that limestone cements, have lower paste water demand than the relative pure cements. Holt and Leivo [3] stated that drying shrinkage is greatly affected by environmental conditions such as wind and humidity in the first days of curing. Sagaraa and Pane [4] revealed that the shrinkage initially tends to be higher for high strength concrete; however the ultimate shrinkage strain is larger for normal strain concrete. Khan and Montgomery [5] concluded that the use of milled limestone in self- compacting concrete with suitable content may reduce drying shrinkage of concrete. Rozie're et al. [6] reported that shrinkage cracking susceptibility increases by increasing the volume of paste and that reducing the volume of paste may affect flowability and surface quality, but it is a way to reduce shrinkage and risk of cracking without affecting strength. Kalkan and Lee [7] had pointed out that the use of SCC makes a beam more vulnerable to restrained shrinkage cracking. Heirman et al. [8] introduced test results which revealed that the SCC mixtures exhibit higher shrinkage and creep deformations compared with the limestone cement concrete mixtures. Leemann et al. [9] attributed the higher shrinkage of SCC mixtures is due to their higher paste volume. For high performance lightweight concrete, Al-Attar and Al-Sakini [10] showed experimentally that using higher lightweight aggregate to binder ratio has negative effect on shrinkage. The results of Gupta et al. [11] gave a conclusion that shrinkage strain of high strength concrete with $10 \%$ fly ash and silica fume replacement were higher by (6-10) \% than concrete without them.

The aim of this research is to investigate the effect of temperature variation on the rate of drying shrinkage development and on ultimate recorded values.

\section{Experimental work \\ 2.1 Materials}

Two types of Portland were used throughout this study. They were ordinary Portland cement, confirms to the ASTM C150-Type I [12], and Portland-limestone cement IL, confirms to the ASTM C595-Type IL [13]. Silica fume with an activity index of $120 \%$ was used as supplementary cementitious material in producing the

* Corresponding author: aalrahamy@yahoo.com 
self-compacting concrete mixes. The silica fume was conforming to the ASTM C-1240 [14] and was added by $10 \%$ as partial replacement of cement for high strength concrete mixes. Table (1) shows the chemical composition and some physical properties for both types of cement and for silica fume.

Table (1). Chemical and physical properties of used ordinary and limestone Portland cement and silica fume

\begin{tabular}{|c|c|c|c|c|c|}
\hline No. & \multicolumn{2}{|c|}{ property } & OPC & IL & SF \\
\hline \multirow{8}{*}{1} & \multirow{8}{*}{ Oxide content, $\%$} & $\mathrm{CaO}$ & 60.8 & 61.3 & $<1$ \\
\hline & & $\mathrm{SiO}_{2}$ & 19.9 & 17.7 & $>85$ \\
\hline & & $\mathrm{Al}_{2} \mathrm{O}_{3}$ & 4.7 & 4.1 & - \\
\hline & & $\mathrm{Fe}_{2} \mathrm{O}_{3}$ & 3 & 4.7 & - \\
\hline & & $\mathrm{MgO}$ & 1.5 & 2.8 & - \\
\hline & & $\mathrm{K}_{2} \mathrm{O}$ & 2.3 & 0.5 & - \\
\hline & & $\mathrm{Na}_{2} \mathrm{O}$ & 0.46 & 0.1 & - \\
\hline & & $\mathrm{SO}_{3}$ & 0.11 & 2.3 & $<2$ \\
\hline 2 & Loss on Igni & O.I) & 2.7 & 5.8 & \\
\hline 3 & Fineness (B & $\mathrm{kg})$ & 309 & 368 & $>15000$ \\
\hline 4 & Specific & & 3.15 & 3.07 & 2.3 \\
\hline 5 & Compressive streng & at 28 days & 42 & 48.4 & - \\
\hline
\end{tabular}

Limestone dust passing sieve $(75 \mu \mathrm{m})$ was added to produce SCC, Table (2) shows the properties of the used limestone dust.

Table (2). Chemical composition of limestone dust

\begin{tabular}{|c|c|c|c|c|c|c|c|c|c|}
\hline Oxide & $\mathrm{SiO}_{2}$ & $\mathrm{Fe}_{2} \mathrm{O}_{3}$ & $\mathrm{Al}_{2} \mathrm{O}_{3}$ & $\mathrm{CaO}$ & $\mathrm{MgO}$ & $\mathrm{SO}_{3}$ & L.O.I & $\mathrm{CO}_{3}$ & $\mathrm{CaCO}_{3}$ \\
\hline Content, \% & 0.21 & 3.36 & 0.03 & 50.84 & 2.99 & 0.08 & 42.2 & 0.19 & 98 \\
\hline
\end{tabular}

Natural sand with fineness modulus of 2.97 and SO3 of $0.3 \%$ was used. Natural crushed coarse aggregate with maximum sizes of $10 \mathrm{~mm}$ and $20 \mathrm{~mm}$ were used. High performance superplasticizer (Sika ViscoCrete -5930) confirming to ASTM C494 Types F [15] was used for producing high strength self- compacted concrete.

\subsection{Concrete mixes and testing program}

Four SCC mixes, AI40 and BI60 for Type I cement and AIL40 and BIL60 for Type IL cement, as shown in Table 3 , were prepared according to the recommendations of ACI Committee 237 [16].

Table (3). Mix details

\begin{tabular}{|c|c|c|c|c|c|c|c|c|}
\hline \multirow[b]{3}{*}{ Mix } & \multirow{2}{*}{\multicolumn{2}{|c|}{ Binder, $\mathrm{kg} / \mathrm{m}^{3}$}} & \multirow{3}{*}{$\begin{array}{c}\text { Limestone } \\
\text { Dust, } \\
\mathrm{kg} / \mathrm{m}^{3}\end{array}$} & \multirow{2}{*}{\multicolumn{2}{|c|}{ Aggregate, $\mathrm{kg} / \mathrm{m}^{3}$}} & \multirow{3}{*}{$\begin{array}{c}\text { Max } \\
\text { Size } \\
\text { of } \\
\text { Agg, } \\
\mathrm{mm}\end{array}$} & \multirow[b]{3}{*}{$\begin{array}{l}\text { Water, } \\
\mathrm{kg} / \mathrm{m}^{3}\end{array}$} & \multirow[b]{3}{*}{$\begin{array}{c}\text { ViscoCrete } \\
\mathrm{L} / \mathrm{m}^{3}\end{array}$} \\
\hline & & & & & & & & \\
\hline & $\begin{array}{c}\text { Cement- } \\
\text { Type }\end{array}$ & $\begin{array}{l}\text { Silica } \\
\text { Fume }\end{array}$ & & F A & $\mathrm{CA}$ & & & \\
\hline AI40 & $400-I$ & \multirow{2}{*}{0} & \multirow{2}{*}{100} & \multirow{4}{*}{764} & \multirow{4}{*}{800} & \multirow{2}{*}{20} & \multirow{2}{*}{152} & \multirow{2}{*}{8} \\
\hline AIL40 & $400-\mathrm{IL}$ & & & & & & & \\
\hline BI60 & $450-I$ & \multirow{2}{*}{50} & \multirow{2}{*}{50} & & & \multirow{2}{*}{10} & \multirow{2}{*}{155} & \multirow{2}{*}{13} \\
\hline BIL60 & 450 - IL & & & & & & & \\
\hline
\end{tabular}

Fresh concrete mixes were tested for self-compactability. $40 \mathrm{MPa}$ was the average required compressive strength at 28 days of cylinders, $\mathrm{d}=100 \mathrm{~mm}$ and $\mathrm{h}=200 \mathrm{~mm}$, for mixes AI40 and AIL40. With w/c ratio of 0.38 and an aggregate maximum size of $20 \mathrm{~mm}$, the attained strength values were 44 and $41 \mathrm{MPa}$ respectively. Mixes BI60 and BIL60 were high strength concrete. They were designed to yield $60 \mathrm{MPa}$ as average required compressive strength at 28 days and they attained 67 and $62 \mathrm{MPa}$ respectively. These mixes were cast with a water/binder ratio of 0.31 and a maximum size of aggregate of $10 \mathrm{~mm}$. For drying shrinkage, prisms of $100 \times 100 \times 400 \mathrm{~mm}$ were exposed to indoor controlled conditions, 21 o $\mathrm{C}$ and $35 \%$ relative humidity, and outdoor conditions, -4 to +39 o $\mathrm{C}$ and 15 to $75 \%$ relative humidity. The drying shrinkage strain was measured according to the ASTM C 157 [17] for a period of 180 days after 7 days of moist-curing for the studied mixes.

\section{Results and discussion \\ 3.1 Fresh SCC results}

Table (4) lists the results of the self-compactability carried out test for the studied SCC mixes. The results revealed that the produced mixes were all conforming to the requirements of the international EFNARC [18]. The 
replacement of Portland cements with silica fume has enhanced the passing and filling abilities of the tested mixes. This behavior could be attributed to the high surface area of silica fume.

Table (4). Fresh SCC test results

\begin{tabular}{|c|c|c|c|c|}
\hline \multirow{2}{*}{ Type of mixes } & \multicolumn{2}{|c|}{ Slump flow } & \multirow{2}{*}{ V-funnel } & \multirow{2}{*}{ L-Box } \\
\cline { 2 - 3 } & $\mathrm{D}$ & $\mathrm{T}_{500}$ & & \\
\cline { 2 - 4 } & $\mathrm{mm}$ & Sec. & Sec. & (H2/H1) \\
\hline AI40 & 750 & 3 & 8 & 0.93 \\
\hline AIL40 & 750 & 3 & 8 & 0.93 \\
\hline BI60 & 790 & 2 & 6 & 0.98 \\
\hline BIL60 & 790 & 2 & 6 & 0.98 \\
\hline EFNARC & $600-800$ & $2-5$ & $6-12$ & $0.8-1$ \\
\hline
\end{tabular}

\subsection{Drying shrinkage behavior for indoor controlled exposure}

Table (5) and Figure (1) show the values and drying shrinkage strain development for the studied mixes when exposed to the indoor controlled exposure, temperature of $21{ }^{\circ} \mathrm{C}$ and $35 \%$ relative humidity.

Table (5). Drying shrinkage strain results in the indoor controlled exposure for the studied SCC mixes

\begin{tabular}{|c|c|c|c|c|}
\hline \multicolumn{5}{|c|}{ Indoor shrinkage strain, $\times 10^{-6}$} \\
\hline \multicolumn{5}{|c|}{$\left(\right.$ Temp $=21^{\circ}$ C, R. H. $\left.=35 \%\right)$} \\
\hline \multirow{2}{*}{$\begin{array}{c}\text { Age, } \\
\text { days }\end{array}$} & \multicolumn{4}{c|}{ Mix } \\
\cline { 2 - 5 } & AI40 & AIL40 & BI60 & BIL60 \\
\hline 3 & 49 & 49 & 38 & 33 \\
\hline 7 & 100 & 85 & 85 & 75 \\
\hline 14 & 150 & 120 & 103 & 96 \\
\hline 21 & 181 & 170 & 155 & 137 \\
\hline 28 & 225 & 205 & 200 & 187 \\
\hline 60 & 293 & 281 & 268 & 237 \\
\hline 90 & 350 & 336 & 316 & 300 \\
\hline 120 & 372 & 359 & 350 & 338 \\
\hline 150 & 427 & 406 & 391 & 363 \\
\hline 180 & 475 & 466 & 438 & 425 \\
\hline
\end{tabular}

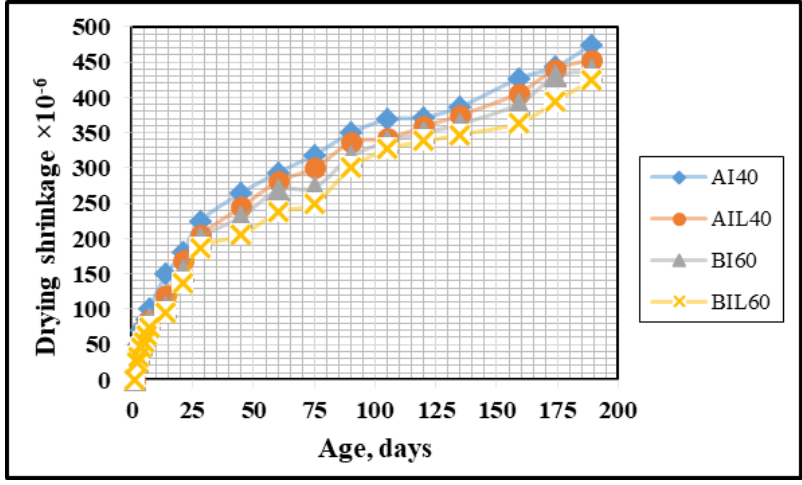

Figure (1). Drying shrinkage behavior of indoor controlled exposure for the studied SCC mixes

Generally, high strength concrete recorded lower drying shrinkage values than normal strength concrete. The ratios of highest shrinkage, at 180 days, for B series mixes to A series mixes were: 92 and $91 \%$ for Types I and IL respectively. This behavior could be explained by that high strength mixes, BI60 and BIL60, have higher bond between aggregate and cement paste because of using aggregate with smaller maximum size, i.e. with higher surface area. This good bond makes the aggregate more effective in restraining the shrinkage strain [19]. The denser interface zone due to the inclusion of silica fume and to using lower w/c ratio could be another factor [20].

Small differences could be observed between shrinkage values for the studied mixes when regarding the type of used cement. Mixes made with Type IL cement showed always lower shrinkage values than those made with Type I cement. The ratios of highest shrinkage strain of Type IL cement to Type I cement mixes were: 98 and 97 for series $\mathrm{A}$ and $\mathrm{B}$ respectively. The difference may be 
due to the smaller clinker to cement ratio of Type IL cement [21].

With respect to rate of shrinkage development, all the studied mixes have almost the same rate and the parallelism of curves shown in Figure (1) could be considered as an indication. According to Figure (1), it could be concluded that the recorded shrinkage values at the end of 180 days, could not be considered as the ultimate shrinkage. The curves at this age do not level at this age and it is expected for these curves to attain higher values at later ages. This observation could be attributed mainly to the controlled temperature and relative humidity which did not allow faster evaporation rate [22].

\subsection{Drying shrinkage behavior for outdoor uncontrolled exposure}

Figure (2) display the temperature variation for the outdoor uncontrolled exposure. This variation was recorded for six months in Baghdad city through the period from $19 / 10 / 2016$ to $19 / 04 / 2017$. The relative humidity in this period had ranged from 15 to $60 \%$. Three intervals could be distinguished in this period: from the starting date to the age of 60 days the average temperature had fallen from 25.5 to $4.5 \mathrm{O} \mathrm{C}$, from 60 to 120 days ages the average temperature stayed with small variation, 4.5 to $11 \mathrm{O} \mathrm{C}$ and finally from 120 days to the end of testing period the average temperature raised from 4.5 to $30 \mathrm{O} \mathrm{C}$.

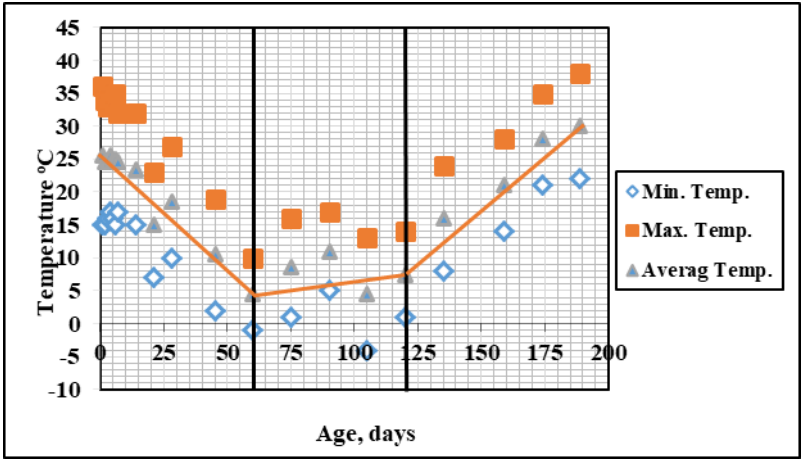

Figure (2). Temperature variation in Baghdad city through the period from 19/10/2016 to 19/04/2017 (outdoor uncontrolled exposure).

Table (6) and Figure (3) show the results of drying shrinkage development in the outdoor uncontrolled exposure for mixes AI40, AIL40, BI60 and BIL60.

Table (6). Drying shrinkage strain results in the outdoor uncontrolled exposure for the studied SCC mixes

\begin{tabular}{|c|c|c|c|c|c|c|c|c|}
\hline \multicolumn{9}{|c|}{ Outdoor shrinkage strain, $\times 10^{-6}$} \\
\hline \multirow{2}{*}{ Age, days } & \multicolumn{4}{|c|}{ Mix } & \multicolumn{3}{|c|}{ Ambient Temperature, ${ }^{\circ} \mathrm{C}$} & \multirow{2}{*}{ R.H., \% } \\
\hline & AI40 & AIL40 & BI60 & BIL60 & Min. & Max. & Av. & \\
\hline 3 & 112 & 101 & 50 & 43 & 15 & 36 & 25.5 & 43 \\
\hline 7 & 196 & 182 & 112 & 100 & 17 & 32 & 24.5 & 40 \\
\hline 14 & 219 & 198 & 137 & 127 & 15 & 32 & 23.5 & 37 \\
\hline 21 & 250 & 235 & 180 & 150 & 7 & 23 & 15 & 40 \\
\hline 28 & 300 & 280 & 210 & 200 & 10 & 27 & 18.5 & 42 \\
\hline 60 & 425 & 390 & 281 & 270 & -1 & 10 & 4.5 & 45 \\
\hline 90 & 550 & 483 & 344 & 315 & 5 & 17 & 11 & 60 \\
\hline 120 & 679 & 660 & 485 & 415 & 1 & 14 & 7.5 & 44 \\
\hline 150 & 723 & 715 & 573 & 513 & 14 & 28 & 21 & 42 \\
\hline 180 & 775 & 759 & 631 & 600 & 22 & 38 & 30 & 15 \\
\hline
\end{tabular}

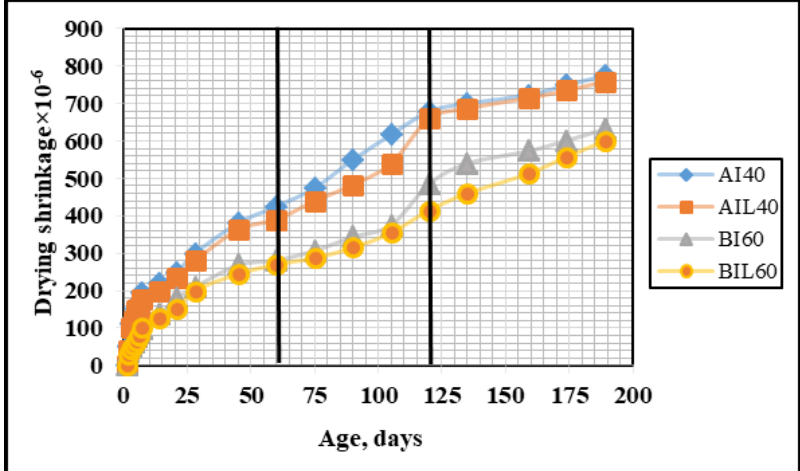

Figure (3). Drying shrinkage behavior of outdoor uncontrolled exposure for the studied SCC mixes
According to the tabulated results it could be assigned that in this exposure the values of shrinkage strain at the age of 180 days were higher than those recorded in the indoor controlled exposure for all mixes. At this age, 180 days, the ratios of ultimate strain of outdoor to indoor exposure were: 163, 163, 144 and 141\% for mixes AI40, AIL40, BI60 and BIL60 respectively. This may be due to the faster rate of drying in the outdoor exposure. This faster rate caused the concrete mixes to attain their ultimate strain values earlier. Although of the ambient temperature fluctuation in this exposure, the total drying shrinkage values were higher. This could be considered 
as an indication to the irreversible nature of most of shrinkage strain. The drop of ambient temperature and the rise of atmosphere moisture or relative humidity would not reverse the shrinkage strain. It is important to figure the final total accumulated strain when dealing with ambient temperature variation.

The ambient temperature fluctuation has affected the rate of shrinkage development. The three above mentioned intervals for temperature variation can be easily assigned on the shrinkage development rate as shown in Figure (3).

The Type IL cement mixes exhibited lower shrinkage strain than Type I cement mixes but the differences were small and the rate was similar. The ratios of ultimate shrinkage strain for Type IL cement mixes to Type I cement mixes were: 98 and 95 for series $\mathrm{A}$ and $\mathrm{B}$ respectively. Therefore, it could be concluded that the drying shrinkage characteristics for concrete made with Type IL cement, ASTM C595, are mostly similar to that produced with Type I cement, ASTM C150.

\section{Conclusions}

1. Portland-limestone cement, ASTM C595 - Type IL, could be used to produce self-compacting concrete with the required filling and passing abilities.

2. For indoor controlled exposure, $21{ }^{0} \mathrm{C}$ and $35 \% \mathrm{RH}$, the recorded shrinkage values at the end of 180 days, could not be considered as the ultimate shrinkage. This observation could be attributed mainly to the controlled temperature and relative humidity which did not allow faster evaporation rate. Meanwhile, at this age in the outdoor uncontrolled exposure concrete mixes attained their ultimate strain values.

3. Although of the ambient temperature fluctuation in the outdoor exposure, the total drying shrinkage values were higher than those of the steady controlled temperature and relative humidity exposure.

4. Due to the irreversible nature of shrinkage strain, the drop of ambient temperature and the rise of atmosphere moisture or relative humidity would not reverse the shrinkage strain. It is important to figure the final total accumulated strain when dealing with ambient temperature variation.

5. The drying shrinkage characteristics for concrete made with Type IL cement, ASTM C595, are mostly similar to that produced with Type I cement, ASTM C150.

\section{References}

[1] K. D. Ingram and K. E. Daugherty, Cement and Concrete Composites, 13, 165-170, (1991).

[2] S.T. Sivilis, E. Chaniotakis and E. Badogiannis, Cement and Concrete Composites, 21,107-116, (1999).

[3] E. Holt and M. Leivo, Cement and Concrete Composites, 26, 521-530, (2004).

[4] A. Sagaraa and I. Pane, Procedia Engineering, 125, 1087 - 1093,(2015)

[5] V. Khan and D. Montgomery, Proceedings of the $1^{\text {st }}$ International RILEM Symposium on Self-Compacting Concrete, Stockholm, Sweden, September (1999)

[6] E. Rosziere, S. Granger, Ph. Turcry and A. Loukili, Cement and Concrete Composites,29, 626-636, (2007).

[7] I. Kalkan and J. H. Lee, KSCE Journal of Civil Engineering, (2013).

[8] G. Heirmana, L. Vandewalle, D. Van Gemert, V. Boel, K. Audenaert, G. De Schutter, B. Desmet and J. Vantomme, Engineering Structures, 30, 2945-2956, (2008).

[9] A. Leeman, P. Lura and R. Loser, Construction and Building Materials, 25, 2283-2289, (2011)

[10] T. S. Al-Attar and J. S. Al-Sakini, International Journal of Civil \& Environmental Engineering, 11, No.6, (2011)

[11] S.M. Gupta, V.K. Sehgal and S.K. Kaushik, World Academy, Engineering and Technology, 50, (2009).

[12] ASTM C150 - 15,Specifications for Portland Cement, Annual Book of ASTM Standards, (2015).

[13] ASTM C595 - 15, Specifications for Blended Hydraulic Cements, , Annual Book of ASTM Standards, (2015).

[14] ASTM C1240 - 15, Specifications for Silica Fume Used in Cementitious Mixtures, Annual Book of ASTM Standards, (2015).

[15] ASTM C494 - 13, Specification for Chemical Admixtures for Concrete, Annual Book of ASTM Standards, (2015).

[16] ACI Committee 237, Self-Consolidating Concrete, ACI237R-07, ACI Manual of Concrete Practice, USA, (2013)

[17] ASTM C157-08, Standard Test Method for Length Change of Hardened Hydraulic-Cement Mortar and Concrete, Annual Book of ASTM Standards, (2015).

[18] EFNARC, Specifications and Guidelines for SelfCompacting Concrete, UK, (2002)

[19] T. S. Al-Attar, Engineering \& Technology Journal, 26, 146-153,(2008).

[20] P. K. Mehta and P. J. M. Monteiro, Concrete Microstructure, Properties and Materials, $3^{\text {rd }} \mathrm{ed} . \mathrm{Mc}-$ Grew Hill, USA, (2006).

[21] T. J. Barrett, H. Sun and W. J. Weiss, Indiana Department of Transportation and Purdue University, USA, (2013).

[22] A. M. Neville, Properties of Concrete, $5^{\text {th }}$ ed. Prentice Hall, UK, (2011). 